$2.4_{\text {RFP-993 }}$
19168
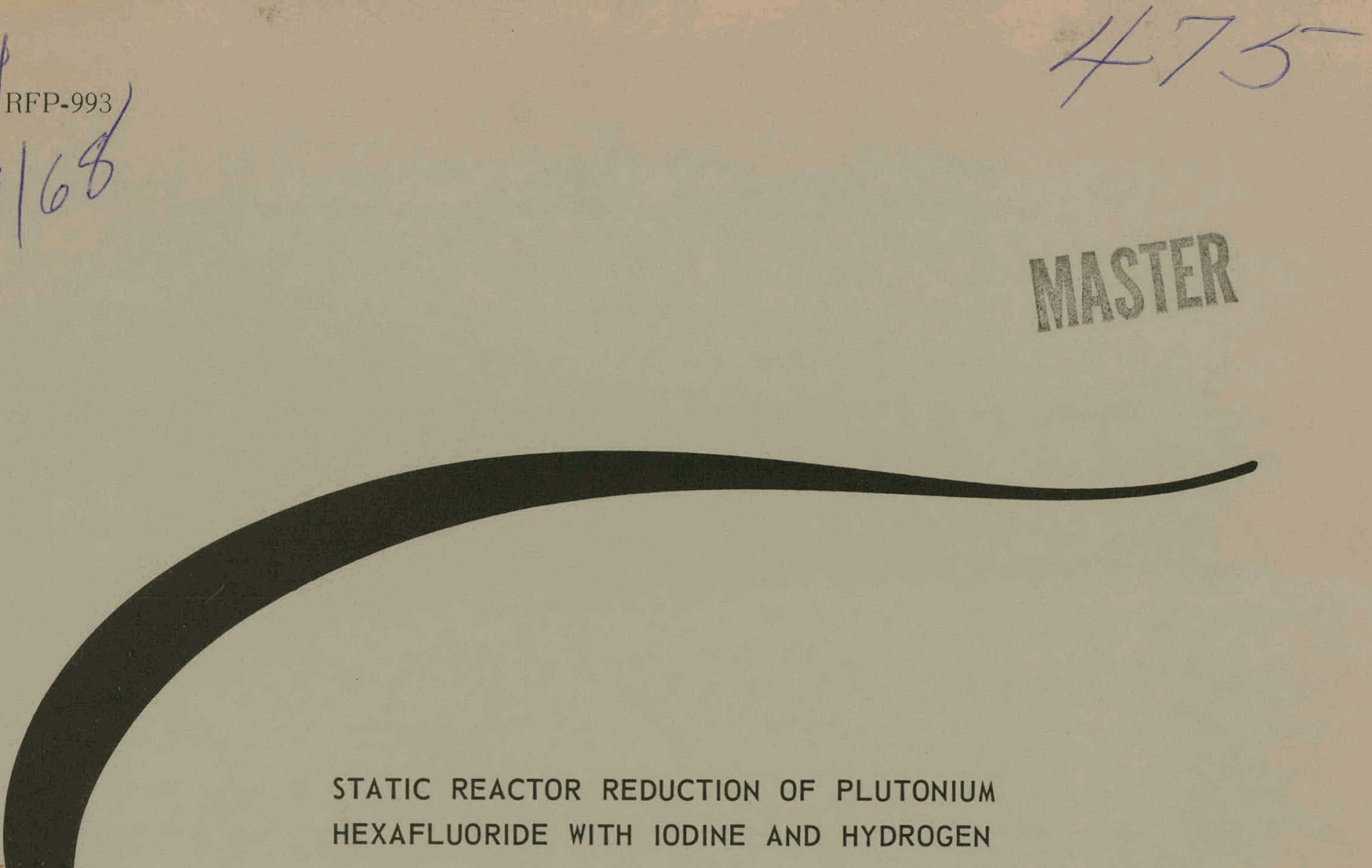

James D. Navratil

Ralph O. Wing

Garrel F. Molen

Jerry D. Moseley

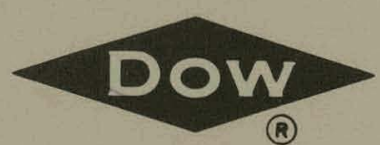

THE DOW CHEMICAL COMPANY

ROCKY FLATS DIVISION

P. O. BOX 888

GOLDEN, COLORADO 80401

U.S. ATOMIC ENERGY COMMISSION

CONTRACT AT(29-1)-1106

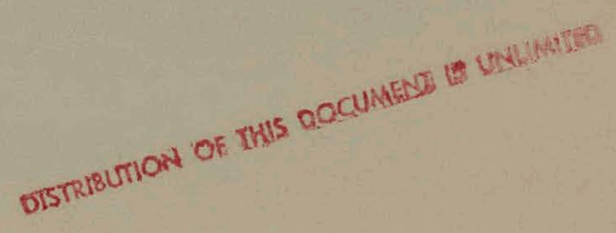




\section{DISCLAIMER}

This report was prepared as an account of work sponsored by an agency of the United States Government. Neither the United States Government nor any agency Thereof, nor any of their employees, makes any warranty, express or implied, or assumes any legal liability or responsibility for the accuracy, completeness, or usefulness of any information, apparatus, product, or process disclosed, or represents that its use would not infringe privately owned rights. Reference herein to any specific commercial product, process, or service by trade name, trademark, manufacturer, or otherwise does not necessarily constitute or imply its endorsement, recommendation, or favoring by the United States Government or any agency thereof. The views and opinions of authors expressed herein do not necessarily state or reflect those of the United States Government or any agency thereof. 


\section{DISCLAIMER}

Portions of this document may be illegible in electronic image products. Images are produced from the best available original document. 


\section{LEGAL NOTICE}

This report was prepared as an account of Government sponsored work. Neither the United States, nor the Commission, nor any person acting on behalf of the Commission:

A. Makes any warranty or representation, expressed or implied, with respect to the accuracy, completeness, or usefulness of the information contained in this report, or that the use of any information, apparatus, method, or process disclosed in this report may not infringe privately owned rights; or

B. Assumes any liabilities with respect to the use of, or for damages resulting from the use of any information, apparatus, method, or process disclosed in this report.

As used in the above, "person acting on behalf of the Commission" includes any employee or contractor of the Commission, or employee of such contractor, to the extent that such employee or contractor of the Commission, or employee of such contractor prepares, disseminates, or provides access to, any information pursuant to his employment or contract with the Commission, or his employment with such contractor.

Printed in the United States of America

Available from

Clearinghouse for Federal Scientific and Technical Information National Bureau of Standards, U. S. Department of Commerce

3pi inglield, Vir yinid 22151

Price: Printed Copy $\$ 3.00$; Microfiche $\$ 0.65$ 
This report was prepared as an account of Government sponsored work. Neither the United States, nor the Commission, nor any person acting on behalf of the Commisston:

A. Makes any warranty or representation, expressed or implied, with respect to the accuracy, completeness, or usefulness of the information contained in this report, or that the use of any information, apparatus, method, or process disclosed in thls report may not infringe privately owned rights; or

B. Assumes any liabilities with respect to the use of, or for damages resulting from the use of any information, apparatus, method, or process disclosed in this report.

As used in the above. "person acting on behalf of the Commission" includes any empioyee or contractor of the Commission, or employee of such contractor, to the extent that such employee or contractor of the Commission, or employee of such contractor prepares, disseminates, or provides access to, any information pursuant to his employment or contract with the Commission, or his employment with such contractor.

TID- 4500

\title{
STATIC REACTOR REDUCTION OF PLUTONIUM HEXAFLUORIDE WITH IODINE AND HYDROGEN
}

\author{
James D. Navratil \\ Ralph O. Wing \\ Garrel F. Molen \\ Jerry D. Moseley
}
THE DOW CHEMICAL COMPANY ROCKY FLATS DIVISION
P. O. BOX 888
GOLDEN, CULURADO 80401
U. S. ATOMIC ENERGY COMMISSION CONTRACT AT(29-1)-1106

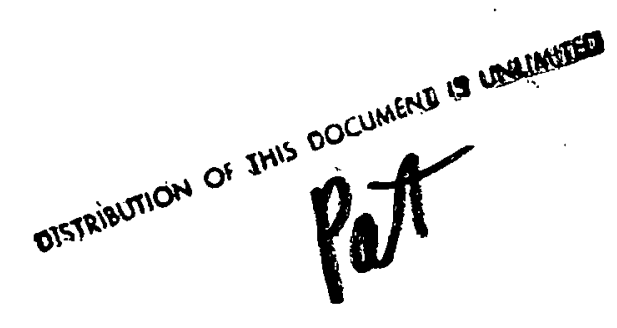


RFP-993 
RFP-993

\section{CONTENTS}

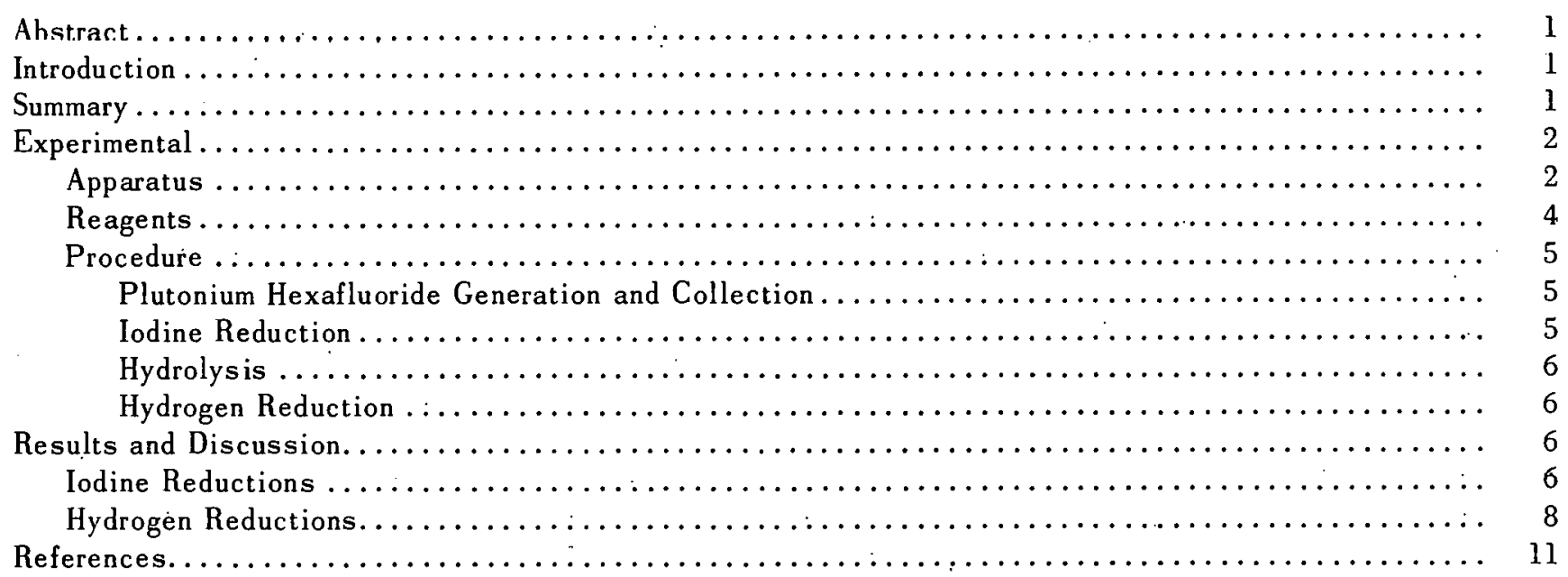




\section{A CK N O W L E D GMENTS}

The authors wish to acknowledge the assistance of the Plutonium Analytical Laburatury, L. F. Grill, Director.

R. S. Marshall was most helpful in correlating data and in editing this report. 


\title{
Static Reactor Reduction of Plutonium Hexafluoride with Iodine and Hydrogen
}

\author{
James D. Navratil, Ralph O. Wing, Garrel F. Molen, and Jerry D. Moseley
}

\begin{abstract}
Experiments are described which are part of an effort to develop and evaluate a plutonium hexafluoride volatility process for the recovery and purification of plutonium from a variety of impure materials.
\end{abstract}

Hydrogen and iodine were used to reduce $\mathrm{PuF}_{6}$ to $\mathrm{PuF}_{4}$. With proper equipment and techniques, both reductants were found to be capable of quantitatively reducing $\mathrm{PuF}_{6}$. $\mathrm{PuF}_{4}$ from $\mathrm{I}_{2}$ reductions was found to contain up to several weight-percent of metallic impurities. $\mathrm{PuF}_{4}$ from the $\mathrm{H}_{2}$ reduction contained from a few hundred parts per million to several weight-percent of metallic impurities. The bulk of the impurities was traced to materials used in construction of the reactor. The results indicate that the $\mathrm{H}_{2}$ reduction step should be investigated further.

Details of equipment and procedures not described in previous reports are included here-in. Reduction bomb pressures and temperatures are given as well as physical and chemical data on the $\mathrm{PuF}_{4}$ product.

\section{INTRODUCTION}

A number of metals, including plutonium, have fluorides that are volatile below $600^{\circ} \mathrm{C}$. The volatile property of plutonium hexafluoride allows purification and resnvery of plutonium from major residues produced in plutonium process streams. Several National Laboratories are investigating fluoride volatility as a process for recovering uranium and plutonium from spent reactor-fuel elements.

Essentially, quantitative removal of plutonium from reactor fuel elements has been demonstrated (1). Conversion of plutonium hexafluoride into a more readily handled form has received little attention. Data on the thermal decomposition of plutonium hexafluoride to plutonium tetrafluoride have been published (2). The reduction of $\mathrm{PuF}_{6}$ to $\mathrm{PuF}_{4}$ with $\mathrm{H}_{2}$ and $\mathrm{I}_{2}$ has been described previuusly $(3,4)$. The reactions of interest are:

$$
\begin{aligned}
& \mathrm{PuF}_{6}+\mathrm{xcH}_{2} \rightarrow \mathrm{PuF}_{4}\left(\mathrm{PuF}_{3}\right)+2 \mathrm{HF}+\mathrm{xcH}_{2} \\
& 5 \mathrm{PuF}_{6}+\mathrm{xcI}_{2} \rightarrow 5 \mathrm{PuF}_{4}+2 \mathrm{IF}_{5}\left(\mathrm{IF}_{7}\right)+\mathrm{xcI}_{2}
\end{aligned}
$$

These two reactions have been further studied to obtain data for possible process applications. This report describes the results of these investigations. Equipment design, plutonium hexafluoride and reductant transfer techniques, reduction yields, reaction temperatures, and product purity data are presented.

\section{SUMMARY}

The $\mathrm{I}_{2}$ reduction of $\mathrm{PuF}_{6}$ to $\mathrm{PuF}_{4}$ was found to be nearly quantitative. Equipment design and reactant transfer technique were found to be important factors influencing the completeness of the reaction and purity of the $\mathrm{PuF}_{4}$ product. The reduction reaction initiated at approximately $4^{\circ} \mathrm{C}$, and gave small temperature and pressure increases in the reduction. bomb. White vapors, attributed to $\mathrm{IF}_{5}$, were sometimes observed evolving from the $\mathrm{PuF}_{4}$ product upon opening the reduction bombs. Iodine reductions resulted in equipment corrosion, handling problems, and product contamination.

Hydrogen reductions of $\mathrm{PuF}_{6}$ were found to be capable of greater than $95 \%$ reduction yields. $\mathrm{PuF}_{4}$ reduction products contained serious contamination from only those elements present in construction equipment, i.e., $\mathrm{Fe}, \mathrm{Ni}, \mathrm{Cr}, \mathrm{Cu}$. Proper equipment design and up-scaling of reduction equipment should result in $\mathrm{PuF}_{4}$ with less than $300 \mathrm{ppm}$ total detectable metallic impurities (5). The rapid reduction reaction initiated at approximately room temperature and gave rise to rapid temperature and pressure rises in the reduction bomb. A clinking noise, as metal striking metal, accompanied the onset of reaction. It appears that the initial reaction consumes $\mathrm{PuF}_{6}$ in the vapor state but not the $\mathrm{PuF}_{6}$ remaining in the liquid or solid state. Continued heating of the reduction bomb was found neressary to produce high reduction yields. This work, coupled with 
other results in a similar $\mathrm{UF}_{6}$ process step, led to the recommendation that the $\mathrm{H}_{2}$ reaction step be studied on a pilot-plant scale.

\section{EXPERIMENTAL}

Apparatus: Figure 1 illustrates the static bed reactor fluorination system including the fluorinator, plutonium hexafluoride product collectors, plutonium hexafluoride reduction bomb, and fluorine disposal system. A complete description of the static bed system including fluorine supply and fluorine disposal may be found elsewhere (6).

In general, plutonium dioxide or tetrafluoride was placed in the sample boat " $A$ " in the static bed reactor " $B$." The furnace was heated to a desired temperature and fluorine was introduced. As plutonium hexafluoride was formed, it was swept out of the furnace and condensed in the reduction bomb "C" and/or product collectors "D." The excess of fluorine continued through the system. and reacted with charcoal in disposal trap "E." Gases leaving the disposal trap $\left(\mathrm{CF}_{4}\right)$ were vented to the drybox atmosphere.

Two types of reduction bombs were used. The first type, called the "unlined bomb," is illustrated in Figure 2a. The unlined bomb was constructed of stainless steel, had a void volume of 115 milliliters, and was equipped with a thermocouple well which terminated approximately 1.5 inches above the bomb bottom. Hoke valves (No. 4213Q6Y) were used on the inlet and outlet lines on the bomb. A copper gasket was used to seal the bomb.

The second type of bomb, lined with Teflon, is illustrated in Figure 2b. This reduction bomb was similar to the unlined bomb in volume, valving, seals, and materials. A liner of Teflon was used to limit the plutonium hexafluoride and fluorinestainless steel contact. To further limit gas-metal contact, the thermocouple well was omitted.

A detailed drawing of the $\mathrm{PuF}_{6}$ product collectors may be found elsewhere (6). These collectors are

Figure 1. Diagram of $\mathrm{PuF}_{6}$ production, collection, and reduction system.

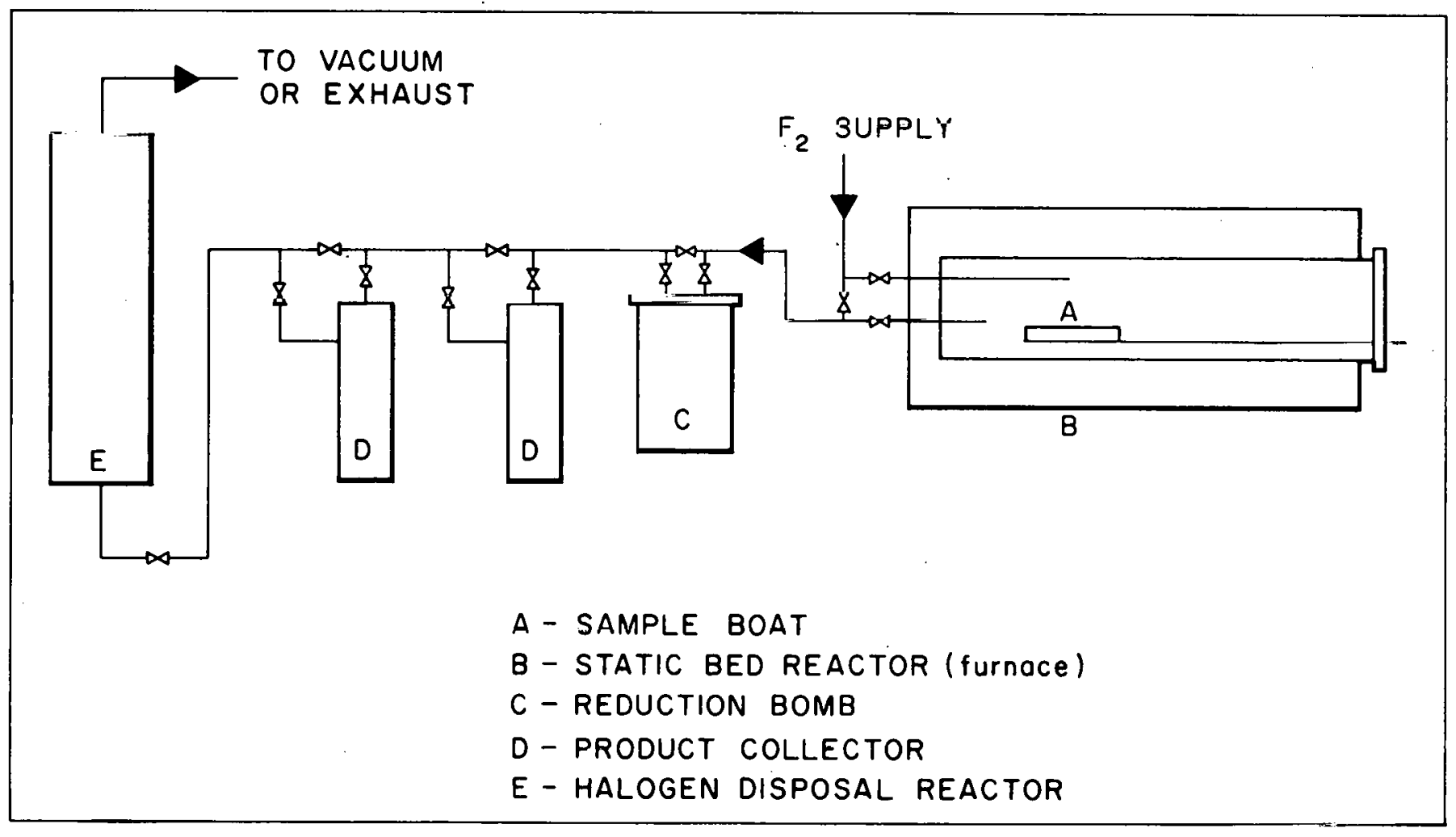




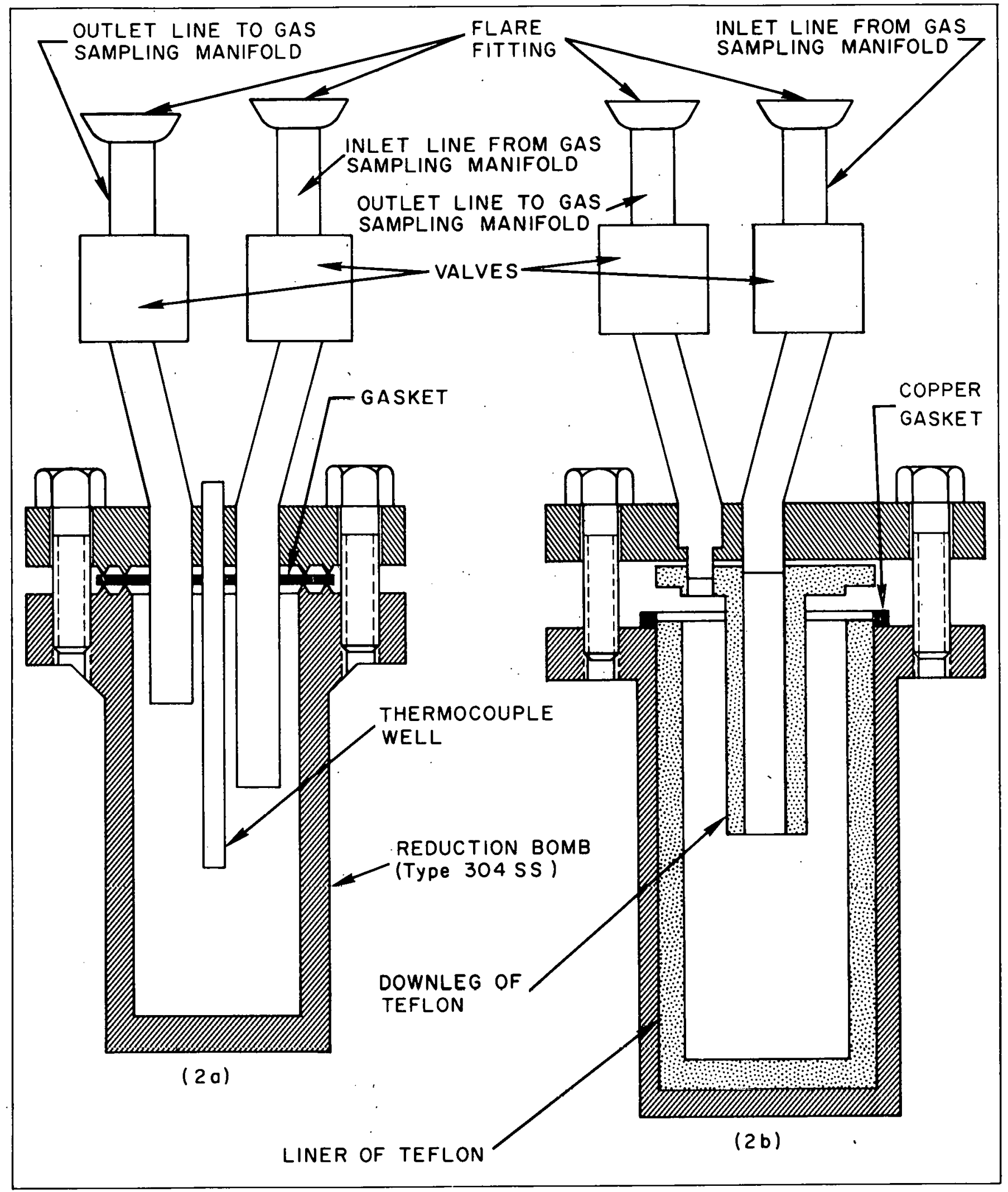

Figure 2. Two types of reduction bombs used in $\mathrm{PuF}_{6}$ reduction studies; (a) unlined, (b) lined with Teflon. 
approximately 8 -inches-high, $3 / 4$-inch i.d., and are equipped with Hoke valves (No. M482M) on the inlet and outlet lines.

For some of the experiments, the gaseous products of the reduction reaction were hydrolyzed in 6-inch by $3 / 4$-inch Kel-F fluorocarbon plastic test tubes. The test tubes were attached to the system using an assembly described by Trevorrow, Kessie, and Steindler (7) and by Moseley and Robinson (6).

A thermocouple of Chromel-Alumel was used to measure temperature changes in the unlined bomb. A Honeywell single point recorder traced bomb temperatures.

An Ashcroft pressure gage was used to mèasure bomb pressure. The measurements were not automatically recorded.

Reduction bombs were heated by either a Master Appliance Corporation heat-gun or in a trichloroethylene bath. The equipment used for heating the bath is shown in Figure 3.

Figure 3. Bath heating apparatus.

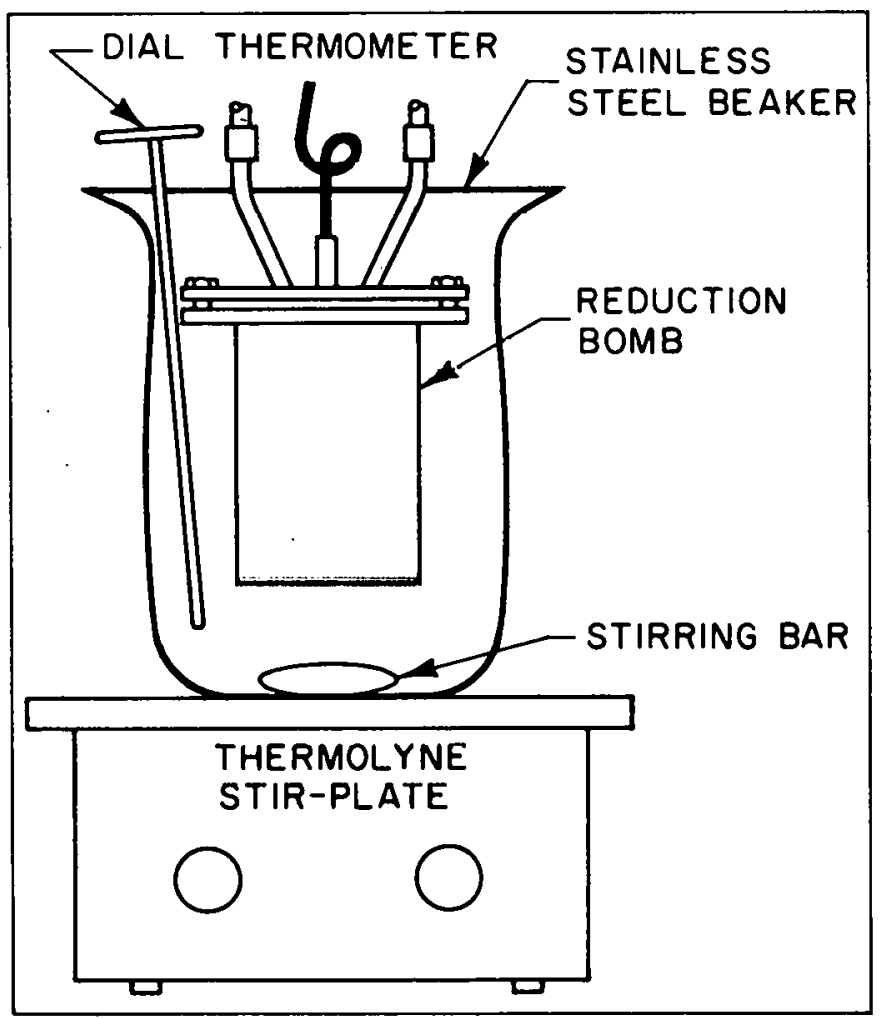

A Thermolyne stir-plate was used to heat a stainless steel beaker containing trichloroethylene. A stir bar coated with Teflon was used to ensure uniform solution temperatures. The reduction bomb was subrnerged in the solution and the bomb and solution temperatures were measured by the thermocouple and by a dial thermometer.

Figure 4 illustrates the hydrogen system. Bottled hydrogen gas passed through a regulator, a flow meter, a drying trap, and into a reduction bomb. Pressure gages were used to adjust precalculated hydrogen pressures in the bomb.

Reagents. Plụtuniuun divxide, plutuniun lelıa* fluoride, and plutonium metal were obtained from the Melal Froduction Group al Rucky Flats. Emission spectrophotometric analyses of these materials showed less than one-weight-percent impurities.

Commercial grade fluorine gas was purchased from the Allied Chemical Corporation. Hydrogen fluoride was removed from the fluorine with a sodium fluoride trap which was heated to $100^{\circ} \mathrm{C}$.

Hydrogen was supplied by the Matheson Company in lecture bottles. The gas was "prepurified" grade and was passed through a molecular sieve trap to remove moisture.

Iodine was purchased from the Deepwater Chemical Company and was U.S.P. grade. The crystals were ground before use, but not further purified.

The hydrolysis solution was $6 \mathrm{M}$ nitric acid and IM aluminum nitrate. Technical grade reagents were used since the hydrolysis solution was only analyzed for plutunium.

Three different reagents were used for fluorine disposal: alumina, soda lime, and charcoal. The activated alumina was supplied by Alcoa and used without further treatment. Soda lime, manufactured by Dewey and Alm Clienical Cunpany, was dried and screened to greater than 4-mesh size before use. Technical grade activated charcoal (4-10 mesh size) was supplied by Cliffs-Dow Chemical Company. The fluorine disposal system is described in detail elsewhere (8). 


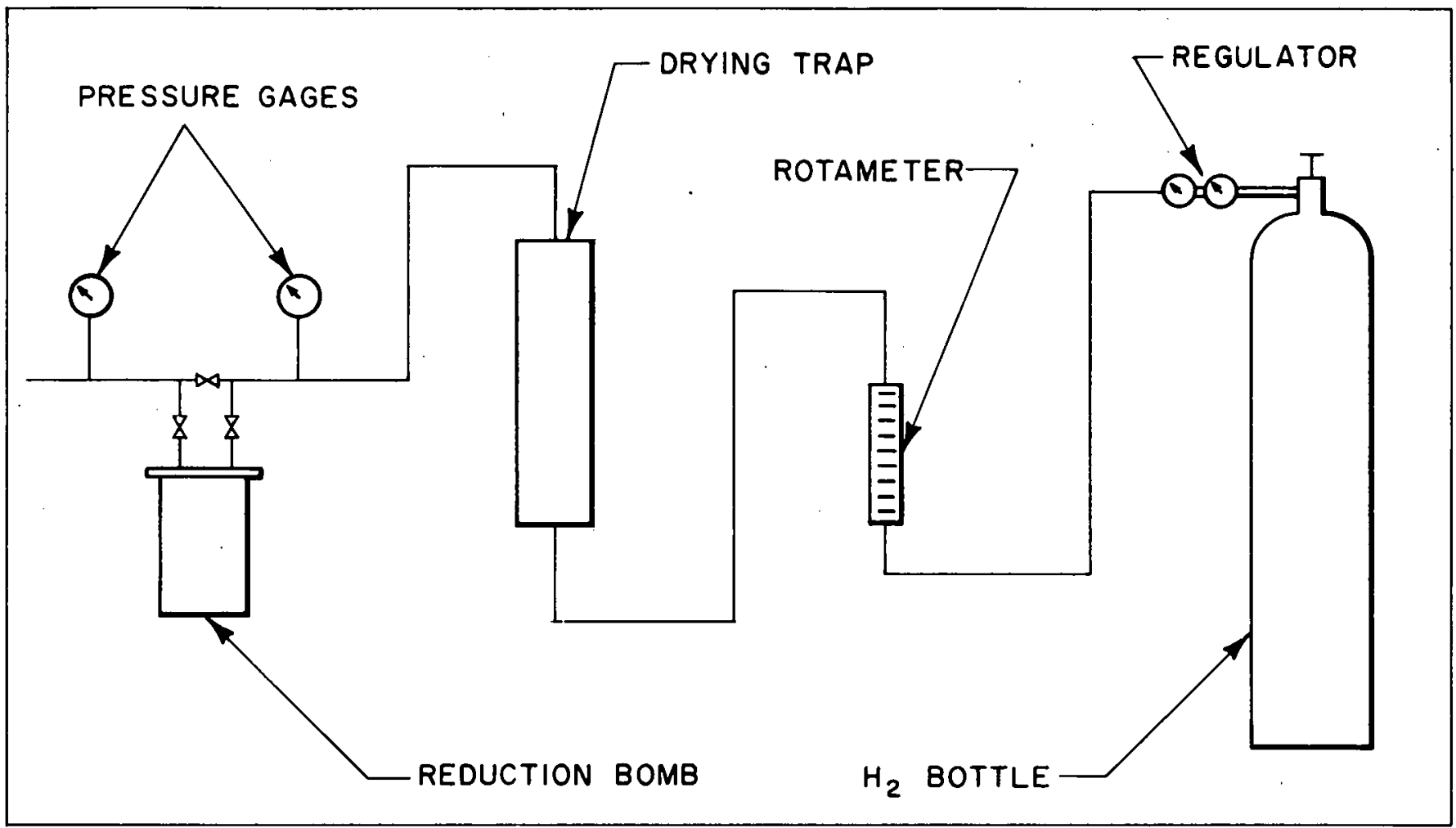

Figure 4. Hydrogen supply system.

\section{Procedure:}

\section{PLUTONIUM HEXAFLUORIDE GENERATION AND} COLLECTION - Plutonium dioxide or tetrafluoride was loaded into the sample boat shown in Figure 1. The boat was placed in the furnace and heated to $550^{\circ} \mathrm{C}$. Fluorine was allowed to flow over the boat for approximately 6 hours. Plutonium hexafluoride evolving from the furnace was condensed in liquid argon-cooled product collectors or in a reduction bomb.

IODINE REDUCTION - Three different procedures were used for iodine reduction experiments:

1. $\dot{A}$ weighed amount of iodine was either directly placed in the unlined bomb or placed in a 4-inchdeep, l-inch-diameter aluminum oxide crucible which was placed in the bomb. The bomb was sealed, connected to the static-bed gas-sample manifold, and evacuated to less than 3 millimeters of mercury. Product collectors containing plutonium hexafluoride were connected to the manifold. The reduction bomb was cooled with liquid argon. Valves between the traps and bomb were opened. Plutonium hexafluoride in the product collectors was vaporized by heating it with a heat-gun. Plutonium hexafluoride condensed in the cooled reduction bomb. Transfer was considered complete when the pressure in the entire system dropped to less than 3-mm mercury. By weighing the cold traps before and after transfer, a theoretical weight of plutonium hexafluoride transferred to the reduction bomb was obtained. A thermocouple was inserted into the thermocouple well and the bomb was allowed to warm to room temperature. The bomb was heated with a heat-gun or allowed to remain at room temperature. When the reaction was considered complete, off-gases were either hydrolyzed or pumped off and the bomb was oponod.

2. The second procedure varied in plutonium transfer technique. Argon at 50- to 100-milliliters per minute was used to dilute and sweep plutonium . hexafluoride from warm cold-traps into the reduction bomb. During transfer, the bomb was either cooled with liquid argon or left at room temperature. 
3. The third procedure varied from the first two in both technique and order of plutonium hexafluoride addition. An empty lined or unlined bomb was evacuated and cooled with liquid argon. Plutonium hexafluoride was transferred into the bomb from collectors as described in the first procedure. The reduction bomb containing plutonium hexafluoride was removed from the manifold system and connected to another steel bomb containing iodine. The reduction bomb was cooled with liquid argon and both bombs evacuated. Valves between the bombs were opened and the iodine bomb heated with a heat-gun. Iodine desublimed in the reduction bomb. The amount of iodine transferred was determined by weighing the iodine bomb before and after transfer,

After transfer, the reduction bomb was allowed to warm to room temperature, then it was heated to $100^{\wedge} \mathrm{C}$, cuoled, evacuaated, and opened.

HYDROLYSIS - A Kel-F fluorocarbon plastic test tube containing 5- to 10 -milliliters of $6 \mathrm{M}$ nitric acid-IM aluminum nitrate solution was frozen with liquid argon. The test tube was connected to the static bed manifold system and evacuated. The reduction bomb was connected adjacent to the test tube. Liquid argon was used to cool the test tube, and the valves between the test tube and bomb were opened. When the gas transfer was complete, the valves to the test tube were closed and the test tube was allnwed in warm gradually to room temperature. The test tube was removed from the manifold, decanted into a sample vial and rinsed with hydrolysis solution. Additional hydrolysis solution was added to adjust the sample to a known volume and the solution was submitted for analysis.

HYUKUGE'N REDUCTIOON - Hydrogen reductions were performed using both lined and unlined reduction bombs. In all hydrogen reduction experiments, plutonium hexafluoride was condensed in the reduction bomb prior to reductant addition. When cold traps were used exclusively as collection vessels, the amount of plutonium hexafluoride transferred to the reduction bomb was determined by weighing the cold traps before and after transfer. In those experiments where the reductiom bomb was used to collect plutonium hexafluoride, back-up cold traps were used and plutonium hexafluoride condensed in these traps was transferred into the reduction bomb. The amount of plutonium hexafluoride collected in the reduction bomb was determined by weighing the bomb before and after collection and transfer.

Plutonium hexafluoride in the reduction bomb was frozen with liquid argon and the bomb was purged with gaseous argon and then evacuated. With the use of pressure as a quantitative indicator, a precalculated amount of hydrogen was introduced into the reduction bomb. When the proper hydrogen pressure was reached, the valves to the reduction bomb and from the hydrogen gas bottle were closed. Residual hydrogen in the manifold was purged through the fluorine disposal traps into the drybox with argon. The entire system was evacuated back to the hydrogen bottle. Care was taken to eliminate all sources of sparks in the drybox during hydrogen venting.

A thcrmocouple of Chromel-Alumel was inserted into the thermocouple well of the unlined bomb. The unlined bomb was heated with a heat-gun aimed at the front and bottom of the bomb. Two experiments were conducted with the unlined bomb without applying heat immediately after hydrogen transfer. The bomb was allowed to remain at room temperature for several hours.

When the bomb lined with Teflon was used, a thermocouple of Chromel-Alumel was taped to the back-center of the bomb. A heat-gun was used to heat the front side of the bomb.

Attempts warn modr to messulu thu plutonium hexafluoride-hydrngen initintion termperuture. An unlined bomb containing plutonium hexafluoride and hydrogen was transferred from a liquid argon bath to a dry ice-trichloroethylene bath. Thermocouples were used in ennjunction with recorder's to follow the silution temperaturo and temperatuse inside the bomb. The solution temperature was alluwed to rise gradually and the temperature at initiation of reaction was noted.

\section{RESULTS AND DISCUSSION}

Iodine Reductions: It has been reported that plutonium hexafluoride reacts with iodine to form plutonium tetrafluoride and iodine pentafluoride or iodine heptafluoride as follows:

$$
\begin{gathered}
5 \mathrm{PuF}_{6}+\mathrm{I}_{2} \rightarrow 5 \mathrm{PuF}_{4}+2 \mathrm{IF}_{5} \\
\mathrm{PuF}_{6}+\mathrm{IF}_{5} \rightarrow \mathrm{PuF}_{4}+\mathrm{IF}_{7}
\end{gathered}
$$


The reduction appears to be a gas-phase reaction : which proceeds rapidly at room temperature (3).

A series of eleven experiments was performed using the first iodine procedure described. Briefly, iodine was loaded into the bomb, the bomb was cooled with liquid argon, and plutonium hexafluoride condensed onto the iodine.

Bomb tcmperature measurements were made during three experiments. In each case a $15^{\circ} \mathrm{C}$ rapid temperature rise was recorded when the bomb temperature reached $4^{\circ} \mathrm{C}$.

In some of the experiments, white fumes evolved upon opening the homb after reduction. The fumes were probably the reaction products of iodine pentafluoride with moisture in the glovebox air (9). The product remaining in the bomb was usually a light pink-salmon colored powder. Analysis of the product revealed small amounts of iodine, and in many. experiments unreacted iodine was observed in the reduction bomb. The unreacted iodine was protected by a coating of $\mathrm{PuF}_{4}$. X-ray diffraction analyses indicated that the product was primarily plutonium tetrafluoride.

Iodine was varied from a two- to five-fold excess over that theoretically required for complete plutonium hexafluoride reduction. No significant product-yield trends could be correlated with the amount of iodine used.

Reduction yields were calculated as follows:

$$
\begin{aligned}
& \text { \% Reduction Yicld }=\frac{\mathrm{mg} \mathrm{Pu} \text { in } \mathrm{PuF}_{4} \text { product }}{\mathrm{mg} \mathrm{Pu} \text { transferred into }} \times 100 \\
& \text { bomb as } \mathrm{PuF}_{6}
\end{aligned}
$$

Average reduction yield for the eleven experiments was $68 \%$. Maximum yield for one experiment was $93 \%$.

A series of experiments was made using the second iodine procedure for reduction. It was hoped that a more quantitative transfer of plutonium hexafluoride could be achieved by sweeping the vaporizing plutonium hexafluoride out of the cold traps with argon gas. In some of the first procedure experiments, the bomb down-leg, through which plutonium hexafluoride was transferred, plugged during transfer. It appears that plugging was caused by iodine condensing in the down leg and reacting with plutonium hexafluoride. Argon purging of plutonium hexafluride into the bomb appeared to eliminate this problem.

In most of the second procedure experiments, the reduction bomb was kept at room temperature during transfer. It was hoped that a continuous, controlled reaction would prove efficient.

During plutonium hexafluoride transfer, 5 to $10^{\circ} \mathrm{C}$ increases were noted and during one experiment, an 80 -millimeter pressure increase was noted. The transfer of plutonium hexafluoride required an excessive amount of time and, because plutonium tetrafluoride was found in the cold traps, it appeared that iodine backstreaming had occurred.

Minimum and maximum yields were 42 and $97 \%$ respectively; however, the number of experiments conducted was not sufficient to provide a meaningful average reduction yield.

Two experiments were conducted using the third iodine procedure for reduction. By condensing plutonium hexafluoride into an empty bomb followed by desublimation of iodine into the bomb, problems encountered in the first two procedures (plugging and backstreaming) were eliminated. It was hoped that better reactant contact would result in higher and more consistent reduction yields than previously obtained, but no yield data were obtained since it was sacrificed for purity data. The bomb lined with Teflon was used in order that meaningful plutonium tetrafluoride purity data could be obtained.

The products from the last two reductions appeared initially to be the normal-pink plutonium tetrafluoride, but upon exposure to the glovebox atmosphere, the powder emitted white fumes and changed to a lightgreen powder, green crystals, and pink flakes. When the fuming had ceased, $x$-ray diffraction analysis showed the product to be plutonium tetrafluoride.

Because of handling difficulties caused by prolonged off-gassing of the product, no emission spectrophotometric analyses were made on tlie pruduct.

Plutonium tetrafluoride produced in the unlinedbomb experiments contained large amounts of metallic impurities. Iron, nickel, and chromium were individually present in the 1000- to 4500-ppm (of $\mathrm{Pu}$ ) range. Plutonium tetrafluoride of acceptable purity (less than $10 \%$ of the mentioned levels) could probably be produced in equipment having suitable construction materials and design. 
Inconsistent yield data probably resulted more from plutonium hexafluoride transfer problems than incomplete reduction. In several experiments, gases present after reduction were hydrolyzed and the resultant solution analyzed radiometrically for plutonium. The maximum plutonium loss in the off gases was found to be only $0.25 \%$ of the plutonium theoretically transferred.

Consistent reduction yields approaching $100 \%$ could probably be achieved with iodine by the use of proper equipment and procedures. It was decided, however, that the reduction of plutonium hexafluoride with hydrogen should be investigated before further iodine reduction experiments were performed. The difficulty of working with gaseous iodine and gasenus iviline fluurides was the primary reason for abandoning this approach.

Hydrogen Reductions: Hydrogen reductions were made, using the bomb lined with Teflon, when product purity and yield were to be determined. The unlined bomb was used when only pressure and temperature changes were to be measured. Starting material for the first product-purity experiment was partially fluorinated plutonium dioxide, whereas feed for the second and third experiments was plutonium dioxide produced by burning plutonium metal in air.

Plutonium tetrafluoride from the lined bomb was a pink-brown powder containing a few agglomerates coated with blue-black substance. The coating was lound to be plutonium trifluoride.

Product analysis indicated that plutonium hexafluoride is reduced by hydrogen as follows:

$$
\begin{aligned}
& \mathrm{PuF}_{6}+\mathrm{H}_{2}(<10 \% \text { excess }) \rightarrow \mathrm{PuF}_{4}+2 \mathrm{HF} \\
& \mathrm{PuF}_{6}+\text { excess of } \mathrm{H}_{2} \rightarrow \mathrm{PuF}_{4}+\mathrm{PuF}_{3}+\mathrm{HF}
\end{aligned}
$$

Feed and product materials were analyzed by emission spectroscopy. Table I contains concentration levels of elements present in the feed and product materials above detection limits. An asterisk is used to indicate that no significant difference in impurity concentration was found between feed and product material. Changes in impurity concentration by a factor of four or greater were considered significant.

Analyses were made for twenty additional cations, and they were found to be present in insignificant quantities (less than $25 \mathrm{ppm}$ ).

The feed for the three experiments was fluorinated from room temperature to $300^{\circ} \mathrm{C}$ during furnace warmup. Below $300^{\circ} \mathrm{C}$, the rate of plutonium hexafluoride formation was very low. During this time, the product collectors were not open to the system. It was hoped that those elements that form volatile fluorides below $300^{\circ} \mathrm{C}$ would be removed from the system and not contaminate the plutonium tetrafluoride reduction product. Elements of this type (Table I) are Ta and Si. Tantalum contamination ili llie product was lower than in the feed. No significant decrease in $\mathrm{Si}$ concentration was observed. Silica contamination of the produrti wao not expected since $\mathrm{SiF}_{+}$has a hoiling point of $-65^{\circ} \mathrm{C}(10)$. Resent. experiments have shown that complete removal of $\mathrm{Si}$ at low flunination temperatures (less than $300^{\circ} \mathrm{C}$ ) may not be possible (11). $\mathrm{SiF}_{4}$ can probably be selectively volatilized from

\begin{tabular}{|c|c|c|c|c|c|c|c|c|c|c|c|c|c|}
\hline $\begin{array}{l}\text { Material } \\
\text { Analyzed }\end{array}$ & $\mathrm{Al}$ & $\mathrm{Be}$ & $\mathrm{Ca}$ & $\mathrm{Cr}_{\mathrm{r}}$ & $\mathrm{C}_{\mathrm{u}}$ & $\mathrm{Fe}_{\mathrm{i}}$ & $r_{\mathrm{ra}}$ & $M g$ & $\mathrm{Ni}$ & $\mathrm{rl}_{\mathrm{I}}$ & 31 & $z_{n}$ & 'l'a \\
\hline $\begin{array}{l}\text { Fced - } \\
\text { Exp. No. I }\end{array}$ & 159 & 100 & 2500 & 21 & 100 & 206 & 2000 & 500 & 428 & $<1$ & 61 & 25 & $\begin{array}{l}1000- \\
10 \%\end{array}$ \\
\hline $\begin{array}{l}\text { Product - } \\
\text { Exp. No. } 1\end{array}$ & 22 & $<0.04$ & 5 & $*$ & 20 & 53 & 11 & 50 & 29 & $*$ & * & $*$ & $<100$ \\
\hline $\begin{array}{l}\text { Feepd - } \\
\text { Exps. 2, } 3\end{array}$ & 308 & 0.08 & 40 & 54 & 100 & 815 & 3000 & 133 & 137 & 35 & 179 & 83 & \\
\hline $\begin{array}{l}\text { Product - } \\
\text { Exp. No. } 2\end{array}$ & 15 & $*$ & .10 & $\dot{*}$ & $*$ & 99 & 20 & 3 & $*$ & $<2.5$ & * & $*$ & \\
\hline $\begin{array}{l}\text { Product - } \\
\text { Exp. No. } 3\end{array}$ & 25 & $*$ & 10 & $*$ & $*$ & 81 & 13 & l & * & $<2.5$ & * & * & \\
\hline
\end{tabular}

'able I. Purification of plutonium by volatilization, and hydrogen reduction of $\mathrm{PuF}_{6}$ (impurities in feed and product matcrial in $\mu_{\mathrm{g}} / \mathrm{g} \mathrm{Pu}$ ). 
$\mathrm{PuF}_{6}$ by warming the $\mathrm{SiF}_{4}-\mathrm{PuF}_{6}$ mixture to $-65^{\circ} \mathrm{C}$ $\mathrm{PuF}_{6}$ has a melting point of $51.6^{\circ} \mathrm{C}(12)$.

Some fluorides of $\mathrm{Cr}$ may be volatile in the 300 to- $550^{\circ} \mathrm{C}$ range. The concentration of $\mathrm{Cr}$ in the feed and product was essentially the same. Chromium contamination of the product may result from a fluorine-stainless steel reaction. The inner surface of the stainless steel tubing between the bomb and valves was exposed to plutonium hexafluoride during transfer and reduction operations. The remaining elements listed in Table $\mathrm{I}$ have fluorides with melting points above $550^{\circ} \mathrm{C}$. The concentration of most of these elements was significantly lower in the product than in the feed. Iron and copper were present as construction materials; therefore, some contamination from these elements was expected. The presence of significant amounts of $\mathrm{Zn}$ in the reduction product was unexpected and is unexplained at this time.

Table II contains further analytical data on the feed and product materials, hydrogen-plutonium hexafluoride mole ratios, and reduction yields. The calculation of reduction yield has been described in the section on Iodine Reduction.

The theoretical weight-percent of plutonium in plutonium tetrafluoride is 75.9. Although the product from Experiment No. 1 had a low plutonium content, the weight-percent plutonium from the products of Experiments 2, 3, and 4 was quite close to the theoretical value.

Summation of weight-percent plutonium and weightpercent fluorine should be equal to 100 if the product was pure plutonium letrafluoride. The totals of the appropriate columns in Table II yield values less than 100 . The weight-percent fluorine values, determined by neutron counting, are not as accurate as the plutonium analyses. Large amounts of plutonium trifluoride could have the effect of lowering weight-percent fluorine values, but a mixture containing $70 \mathrm{w} / \mathrm{o}$ plutonium trifluoride$30 \mathrm{w} / \mathrm{o}$ plutonium tetrafluoride would be necessary to reduce the weight-percent fluorine value to 20.7 . $\mathrm{X}$-ray diffraction analyses showed that only a small $(<10 \mathrm{w} / \mathrm{o})$ amount of plutonium trifluoride was in the samples.

From the equations shown, it can be seen that a theoretical $\mathrm{H}_{2} / \mathrm{PuF}_{6}$ mole ratio of $\mathrm{l}$ is required for quantitative plutonium hexafluoride reduction to plutonium tetrafluoride. Experiment No. 4 showed that satisfactory reduction yields could be obtained with a slight excess of hydrogen $\left(\mathrm{H}_{2} / \mathrm{PuF}_{6}\right.$ mole ratio of 1.08$)$.

The $75 \%$ yield obtained in Experiment No. 2 can be attributed, in part, to a loss of plutonium tetrafluoride during a check of the bomb pressure after reduction. Experiment No. 4 was conducted in the unlined bomb. Only yield data, in addition to temperature and pressure increase data, were obtained. It is believed that with improved techniques, reduction yields above $99 \%$ could be consistently obtained. This opinion is based on the work described in this report and on previous work where $\mathrm{UF}_{6}$ was reduced in a similar manner (5).

Several experiments were performed to determine the reduction reaction-initiation temperature, pressure increase during the reaction, and temperature rise during the reaction. The unlined bomb was heated with a heat.-gun as previously described. Unfortunately, the thermocouple was situated in a

Table Il. Analytioal, ohemical, and yield data from reduction experiments.

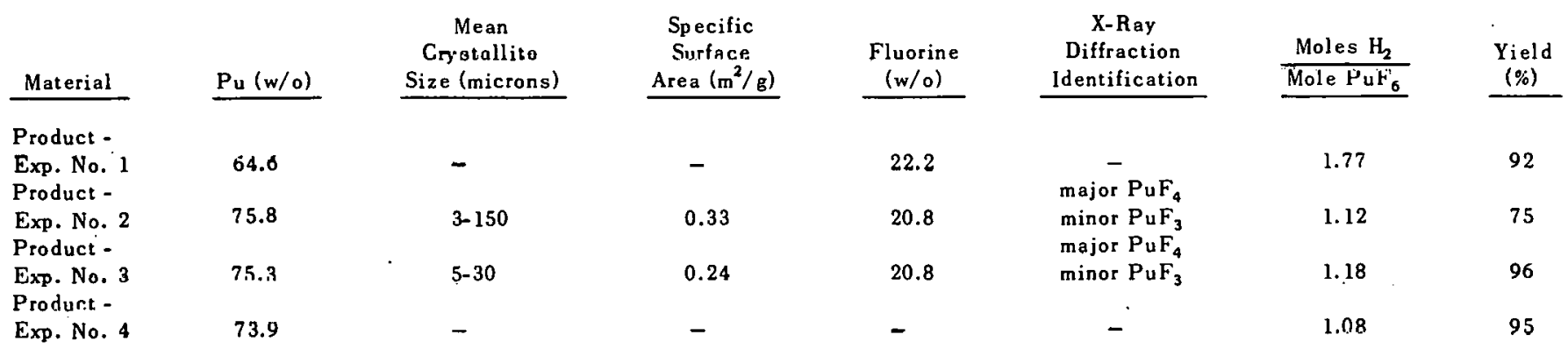


well about 1.5 inches from the bottom of the bomb and the temperatures measured were lower than the temperature of the heated wall. Pressure readings were made visually on a 0 - to 200 -psi pressure gage.

The reaction was initiated between 20 and $25^{\circ} \mathrm{C}$ in three experiments, but occurred at $0^{\circ} \mathrm{C}$ in the fourth cxpcriment. A rapid temperature rise followed initiation and varied from 40 to $60^{\circ} \mathrm{C}$. Figure 5 shows temperature measurements taken before, during, and after the reaction.

Two additional experiments were performed in which the unlined bomb was slowly heated in a trichloroethylene bath from 15 to $55^{\circ} \mathrm{C}$. The solution and bomb thermocouple temperatures were maintained within $2^{\circ} \mathrm{C}$ of each other. The first reduction initiated at $25^{\circ} \mathrm{C}$, hut in the second experiment the reaction still had not occurred at the trichloroethylene boiling point (approximately $60^{\circ} \mathrm{C}$ ).
The heat-gun was applied to the bomb wall and the reaction initiated at approximately $70^{\circ} \mathrm{C}$. It appeared that the reaction initiation-temperature was influenced by uncontrolled variables such as wall effects or trace impurities. No further experiments of this type were made.

A rapid pressure rise occurred upon reaction as is shown in Figure 6. Although the amount of plutonium hexafluoride and hydrogen in the reduction bomb was approximately the same in each experiment, the peak pressure observed varied from 120 -psi to greater than $200-p s i$ gage limit. It should be noted that the pressure at initiation of the reaction is more ronstant (65-70 psi) than is the temperalure at ignition.

Two experiments were made in which the reduction bomb was allowed to warm to room temperature

Figure 5. Temperature of ignition, rate of temperature rise, and maximum temperature measured for the static-bomb reaction: $\mathrm{PuF}_{6}+\mathrm{H}_{2} \rightarrow \mathrm{PuF}_{4}+2 \mathrm{HF}$. Numbers refer to experiment numbers.

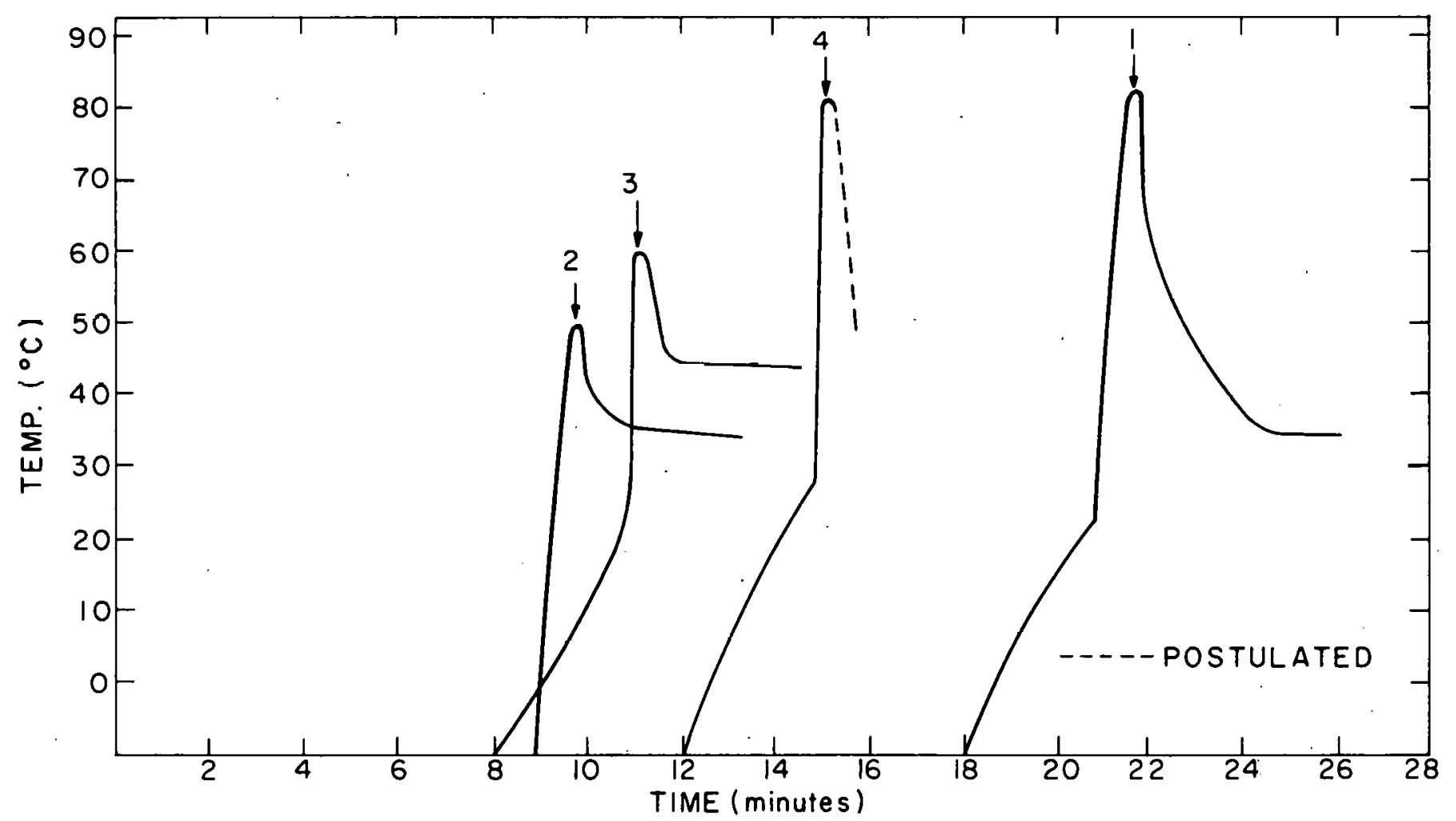




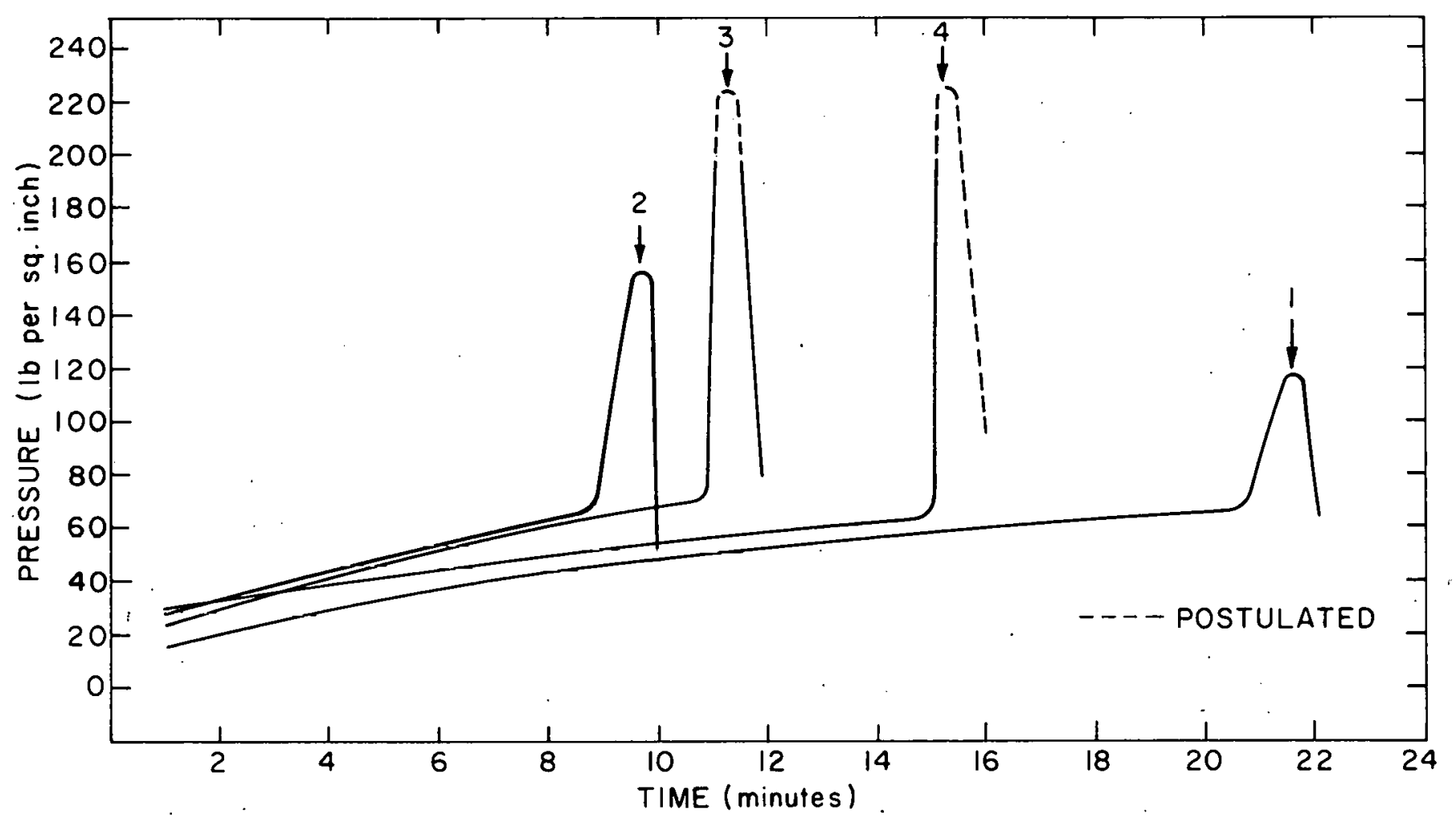

Figure 6. Pressure at initiation of reaction and maximum pressure measured for the static bomb reaction: $P_{4} F_{6}+H_{2} \rightarrow$ $\mathrm{PuF}_{4}+2 \mathrm{HF}$. Numbers refer to experiment numbers.

without heating. In the first experiment a temperature rise of $60^{\circ} \mathrm{C}$ was noted after 64 minutes. The bomb was evacuated for 2 minutes and opened. White vapors evolved for several minutes. Similar vapors were observed upon opening the reduction bomb in the first trichloroethylene bath experiment. The reduction yield from this experiment was only 54 percent.

Another experiment was conducted in which the bomb was allowed to remain at room temperature for 17 hours. At the end of that time, the bomb was heated with the heat-gun. A rapid temperature rise of $17^{\circ} \mathrm{C}$ was noted. No fumes were observed upon opening the bomb.

It appears that plutonium hexafluoride in the liquid or solid state in the bomb is not reduced when the gas-phase reaction occurs. The application of external heat is necessary to obtain good yields. Initiation temperature of the gas- phase reaction was not determined with certainty, but it is probably at room temperature or higher.

The hydrogen reduction of gaseous plutonium hexafluoride appears to be a practical prucess. Using unsophisticated equipment, favorable reduction yields and product purity were obtained. Hydrogen has been selected as a reductant for plutonium hexafluoride to be generated in the Rocky Flats fluid bed fluoride volatility pilot plant.

\section{REFERENCES}

1. Reactor Development Program Progress Repurt - March 1067, Argonne Natinnal I.aboratory, Report No. 7317, pp 84-85. 
2. L. Trevorrow, J. Fischer, and J. Riha, "Separation of Gaseous Mixtures of Uranium Hexafluoride and Plutonium Hexafluoride by Thermal Decomposition," Argonne National Laboratory, Report No. 6762, August 1963.

3. M. J. Steindler, "The Properties of Plutonium Hexafluoride," Argonne National Laboratory, Report No. 6753, August 1963.

4. N. J. Hawkins, KAPL-1334, pp 89 (1955).

5. S. H. Smiley, et al., "Development of the Continuous Method for the Reduction of Uranium Hexafluoride with Hydrogen - Prnresss Development. Cold Wall Reactor." Union Carbide Nuclear Lompany Report K-1248, May 22, 1956.

6. J. D. Moseley and H. N. Robinson, "Static Bed Reactor for Studies of a Plutonium Hexafluoride Volatility Process," RFP-1048, Rocky Flats Division, The Dow Chemical Company, December 11, 1967.
7. L. E. Trevorrow, R. W. Kessie, and M. J. Steindler, "Analysis of an Accidental Multigram Release of Plutonium Hexafluoride in a Glovebox," Argonne National Laboratory, Report No. 7068, pp 7, July 1965.

8. J. D. Navratil, "Disposal of Fluorine," RFP-1200, Rocky Flats Division, The Dow Chemical Company, August 29, 1968.

9. P. J. Durrant and B. Durrant, Advanced Inorganic Chemistry, p 904, John Wiley and Sons, Inc., New York, 1962.

10. Lange, Handbook of Chemistry, pp 302, McGrawHill Book Company, Inr.., New York, 1961.

11. J. D. Navratil and R. O. Wing, "Impurity Removal by Fluorination of Plutonium Dioxide Between 28 and $300^{\circ} \mathrm{C}$," RFP-1052, Rocky Flats Division, The Dow Chemical Company, September 1968.

12. B. Weinstock, E. E. Weaver, and J. G. Malm, J. Inorg. Nucl. Chem., 11, 104 (1959). 